\title{
Between Discursive and Exclusive Autonomy - Opinion 2/13, the Protection of Fundamental Rights and the Autonomy of EU Law
}

\author{
Benedikt H. PIRKER and Stefan REITEMEYER* \\ Institute for European Law, University of Fribourg
}

\begin{abstract}
EU Opinion 2/13 on the accession of the EU to the ECHR was a landmark decision of the Court of Justice of the EU both for fundamental rights protection in the EU and the autonomy of the EU legal order. The present article argues that two approaches would have been possible, following either a discursive or an exclusive understanding of autonomy. As a thorough discussion of the Opinion shows, the Court chose the latter pathway, with detrimental consequences for the foreseeable future.
\end{abstract}

Keywords: fundamental rights, autonomy of EU law, European Convention on Human Rights, Common Foreign and Security Policy, dispute settlement, Court of Justice of the European Union

\section{INTRODUCTION}

Opinion $2 / 13^{1}$ on whether the draft agreement ${ }^{2}$ for accession of the European Union (EU) to the European Convention on Human Rights and Fundamental Freedoms (ECHR) is compatible with the Treaties evoked many voices commenting on the decision. Many commentators were highly critical and lamented a 'human rights gap' in the EU legal system caused, or respectively not filled by, the Court of Justice of the $\mathrm{EU}(\mathrm{CJEU}) .^{3}$ From a human rights point of view, this perception is certainly partly true.

* The present article is based on a previous short comment by the authors in German on Opinion 2/13 published in Jusletter: BH Pirker and S Reitemeyer, 'Zum Gutachten 2/13 des EuGH über den Beitritt der EU zur EMRK' (23 March, 2015) Jusletter http://www.jusletter.ch [last accessed 8 July 2015]. The authors thank Markus Kern and Sian Affolter for helpful comments on earlier versions of this paper.

1 Opinion 2/13 (ECHR Accession II), EU:C:2014:2454.

2 Final report to the CDDH, Council of Europe, 47+1(2013)008rev2.

3 LFM Besselink, 'Acceding to the ECHR Notwithstanding the Court of Justice Opinion 2/13' (23 December 2014) Verfassungsblog http://www.verfassungsblog.de [last accessed 8 July 2015]; S Douglas-Scott, 'Opinion 2/13 on EU Accession to the ECHR: A Christmas Bombshell From the European Court of Justice' (24 December 2014) UK Constitutional Law Blog http://ukconstitutionallaw. org [last accessed 8 July 2015]; PJ Kuijper, 'Reaction to Leonard Besselink's ACELG Blog' (6 January 2014) Amsterdam Centre for European Law And Governance http://acelg.blogactiv.eu [last accessed 8 July 2015]; T Lock, 'Oops! We Did it Again - the CJEU's Opinion on EU Accession to the ECHR' (18 December 2014) Verfassungsblog http://www.verfassungsblog.de; A O'Neill, 'Opinion 2/ 13 on EU Accession to the ECHR: The CJEU as Humpty Dumpty' (18 December 2014) EUtopia law 
The EU missed an opportunity to take a further step towards filling in a blank spot on the map of members to the ECHR. Some authors also criticised the 'no, unless' tone of the judgment with regard to the compatibility of the draft agreement with the Treaties, leaving a rather negative impression of the Court's views on accession, while Advocate General Kokott decided to frame her opinion rather on a 'yes, if' approach.

More understanding views pointed out the role of the CJEU as a supreme, and not just a human rights, court making the CJEU a guardian not only for human rights but also for the constitutional framework of the EU. ${ }^{5}$ From the constitutional point of view, one can understand the Court's emphasis on the autonomy of the EU legal order. The autonomy of the EU in its international and regional context has for a long time been one of the most important characteristics for the CJEU. Starting with Van Gend en Loos, ${ }^{6}$ the CJEU established the autonomy of the EU in a comprehensive jurisprudence for both internal (e.g. MOX-Plant ${ }^{7}$ ), and external (e.g. GATS, ${ }^{8}$ Patent Court $^{9}$ and Kadi $^{10}$ ) relations.

It is with the latter point in particular in mind that the present contribution intends to focus on the notion of autonomy that underlies the reasoning of the Court, of Advocate

(F'note continued)

http://eutopialaw.com [last accessed 8 July 2015]; S Peers, 'The CJEU and the EU's Accession to the ECHR: A Clear and Present Danger to Human Rights Protection' (18 December 2014) EU Law Analysis http://eulawanalysis.blogspot.com [last accessed 8 July 2015]; S Peers, 'The EU's Accession to the ECHR: The Dream Becomes a Nightmare' (2015) 16 (1) German Law Journal 213; M Wendel, 'Mehr Offenheit wagen! Eine kritische Annäherung an das Gutachten des EuGH zum EMRK-Beitritt' (21 December 2014) Verfassungsblog http://www.verfassungsblog.de.

4 See J Odermatt, 'A Giant Step Backwards? Opinion 2/13 on the EU's Accession to the European Convention on Human Rights' (2015) 150 KU Leuven Working Paper, p 12; SO Johansen, 'Opinion 2/13: A Bag of Coal From the CJEU' (10 January 2015) Pluri Courts Blog http://blogg.uio.no/jus/smr/multirights/ [last accessed 8 July 2015].

5 K Bachi, 'EU Accession to the ECHR: In Defense of the ECJ (25 February 2015) Jean Monet Saar http://jean-monnet-saar.eu?p=745 [last accessed 8 July 2015]; C Barnard, 'Opinion 2/13 on EU Accession to the ECHR: Looking for the Silver Lining' (16 December 2015) EU Law Analysis http:// eulawanalysis.blogspot.com; A Duff, 'The European Union is in Deep Trouble With its Top Court' (7 January 2015) BlogActiv EU http://andrewduff.blogactiv.eu [last accessed 8 July 2015]; A Duff, 'EU Accession to the ECHR: Politicians to the Rescue?' (14 March 2015) BlogActiv EU http://andrewduff. blogactiv.eu; D Halberstam, 'It's the Autonomy, Stupid!' A Modest Defense of Opinion 2/13 on EU Accession to the ECHR, and the Way Forward' (2015) 16 (1) German Law Journal 106; U Haltern, 'Die Quittung für Verfassungsneid' (29 January 2015) Neue Zürcher Zeitung, p 21, http://www.nzz.ch/ meinung/debatte/die-quittung-fuer-verfassungsneid-1.18471041 [last accessed 8 July 2015]; JP Jaqué, 'Non à l'adhésion à la Convention Européenne des Droits de l'homme?' (13 December 2014) Droit de l'Union européenne http://www.droit-union-europeenne.be [last accessed 8 July 2015]; C Krenn, 'Autonomy and Effectiveness as Common Concerns: A Path to ECHR Accession After Opinion 2/13' (2015) 16 (1) German Law Journal 147; H Labayle, 'La guerre des juges n'aura pas lieu. Tant mieux? Libres propos sur l'avis 2/13 de la Cour de justice relatif à l'adhésion de l'Union à la CEDH' (22 December 2014) http://www.gdr-elsj.eu [last accessed 8 July 2015].

6 Van Gend en Loos v Administratie der Belastingen, C- 26/62, EU:C:1963:1.

7 Commission v Ireland, C-459/03, EU:C:2006:345.

8 Opinion 1/94 (GATS Agreement), EU:C:1994:384.

9 Opinion 1/09 (Unified Patent Litigation System), EU:C:2011:123.

10 Kadi and Al Barakaat International Foundation v Council and Commission, C-402/05 P, EU: $\mathrm{C}: 2008: 461$. 
General Kokott, and of various commentators in the context of Opinion 2/13. Our argument is that the Opinion can best be understood having in mind a continuum between a discursive and an exclusive understanding of autonomy, on which the Court has regrettably opted predominantly for exclusiveness. To put the Opinion in context, we start with a short historical overview. Then our understanding of a discursive and an exclusive reading of autonomy is set out. After that, the article follows the five step order of Opinion 2/13 and thus examines both human rights and constitutional law based arguments on the subject of autonomy, Article 344 of the Treaty of the European Union (TFEU), the co-respondent-mechanism, Protocol 16 to the ECHR, and the Common Foreign and Security Policy (CFSP) in the light of the notions of discursive and exclusive autonomy. A last section concludes with an outlook on where the Court's decision to opt for exclusive autonomy leaves us.

\section{HISTORICAL OVERVIEW}

The planned accession of the EU to the ECHR pursues the objective of increasing the effectiveness and homogeneity of fundamental rights protection in Europe. ${ }^{11}$ The very idea of accession goes back to 1974 when France ratified the ECHR, and the German Constitutional Court criticised the inadequate protection of fundamental rights in the European Economic Community in its well-known Solange I decision. ${ }^{12}$ While the European Commission already favoured accession in 1979 and tried to convince the Council of its idea again in 1990, only in 1994 did the latter ask the CJEU for a legal opinion. In its Opinion $2 / 94^{13}$ however, the Court insisted that the Treaties lacked an appropriate legal basis for accession. ${ }^{14}$ With the Treaty of Lisbon, accession is now provided for in Article 6 (2) TEU. Consequently, on 4 June 2010 the Council gave a mandate to the Commission to start negotiations with the Council of Europe on accession of the EU to the ECHR. After the conclusion of negotiations the Commission asked the Court for an Opinion on the draft agreement reached in the negotiations. ${ }^{15}$

The Opinion handed down by the Court in December 2014 was adequately designated as a veritable 'Christmas bombshell'. ${ }^{16}$ Not only did the Court find a number of elements to criticise, as could already have been expected after the opinion of Advocate General Kokott delivered in June $2014{ }^{17}$, but it eventually decided that the draft agreement was incompatible with the Treaties and developed a

\footnotetext{
11 Opinion of Advocate General Kokott in Opinion 2/13 (ECHR Accession II), EU: C:2014:2475, para 1 .

12 German Constitutional Court 2 BvL 52/71, (Solange I), BVerfGE 37, 271.

13 Opinion 2/94 (ECHR Accession I), EU:C:1996:140.

14 Ibid, para 35.

15 For a short overview see R Streinz and W Michl 'Article 6 EUV' in R Streinz (ed), Kommentar EUV/AEUV (CH Beck, 2012) para 7 et seq.

$16 \mathrm{~S}$ Douglas-Scott, see note 3 above.

17 See note 11 above, para 280.
} 
highly demanding reasoning rendering future accession quite a difficult task, as is subsequently set out in more detail.

\section{DISCURSIVE VERSUS EXCLUSIVE AUTONOMY}

It could be expected from the outset that the concept of autonomy of EU law would play a central role in the Opinion handed down by the Court. It is at this point that introducing the notions of discursive and exclusive autonomy as a conceptual approach can help structure the subsequent discussion of the Court's statements. There is no uniform definition as to how autonomy must play out, in particular with regard to external judicial bodies' ability to speak out on matters of EU law and interpret it for this purpose. Arguably, there is a continuum between two poles: under a discursive understanding of autonomy, the Court would to some extent be open to the idea that EU law is discussed more broadly also by external actors. International dispute settlement institutions could in some cases utter their view on EU law if adequate precautions against binding interpretations were taken. The shape of autonomy therefore would gain its definition by both internal and external processes. To put it differently, the autonomy of the EU would be shaped by the EU acting in concert with its partners in international conventions and agreements. The self-perception of discursive autonomy is one of confidence, as the possibility that other judicial actors may engage in a discussion of EU law is not seen as a threat per se.

Exclusive autonomy, on the other hand, opens its discussions only to stakeholders and is therefore closed for parties outside the EU. The shape of autonomy is defined only by internal processes and excludes as much as possible external influences. Any views handed down by international dispute settlement mechanisms will need to be accompanied by extensive safeguards or even be excluded under this view. By excluding external influences, the self-perception is one of a rigid autonomy that needs to be shielded from dilutive external influences. For this reason, exclusive autonomy might prove inflexible in negotiations with stronger partners who are not willing to accept extensive provisions made to shield such a conception of autonomy.

The distinction drawn for the purposes of the present paper can also be explained through the lenses of recent attempts to describe and analyse the relationship between the EU and the international legal order. An exclusive approach is arguably more in line with a pluralist perspective: the latter would emphasise primarily the co-existence of legal orders and the unhindered application of the foundational principles of each order, even at the cost of another legal order's full effectiveness. ${ }^{18}$ Less trust is put in other courts. A discursive approach pursues a more integrationist rationale and requires courts to accept as a matter of principle that there are other courts with their own jurisdiction. Furthermore, they must not overextend their own

18 See eg G De Búrca, 'The European Court of Justice and the International Legal Order After Kadi' (2010) 51 (1) Harvard International Law Journal 1. 
exclusive jurisdiction to the detriment of others, and should not assume that other courts will misuse their powers. ${ }^{19}$

In our view, the Court's decision in Opinion 2/13 seems to follow a predominantly exclusive approach. ${ }^{20}$ That this was not necessarily the only option available can already be shown by taking into regard the other EU-internal stakeholders whose views the CJEU shut out together with the feared external influences on autonomy. Not only the European Commission ${ }^{21}$, but also the European Parliament, the Council ${ }^{22}$ and Advocate General Kokott, ${ }^{23}$ were in favour of accession as a matter of principle under the terms of the draft agreement, as well as all 24 intervening Member States. ${ }^{24}$ One could say that except for the plenary of the Court, all stakeholders of the EU thought the autonomy of the EU legal order was strong enough to open up to external influences in the field of human rights. ${ }^{25}$ In this regard, the Opinion might be observed as a political move by the Court to strengthen its position towards the EU bodies and Member States by overruling them (in this rather harsh and brief decision). One could also suggest that Opinion 2/13 also reveals a rather weak self-perception of the Court as it valiantly fights any attempt to draw limits to its jurisdiction.

The Court turned down nearly all stakeholders within the EU and left them with a rather short explanation of its position and reasoning in order to strengthen autonomy. This strong focus on shielding the autonomy of the EU not only displays the CJEU's lack of confidence in the strength of the autonomy of EU law but also leaves the latter in a weaker position ${ }^{26}$ for negotiations of future international agreements with strong partners like the planned Transatlantic Trade and Investment Partnership with the USA. ${ }^{27}$

As these outcome-related concerns already indicate, it can be shown that in its opinion, the Court followed a predominantly exclusivity-based rationale and missed a number of occasions to aim for a more discursive conception of autonomy. We demonstrate this in the following discussion of each of the sections of the Opinion, namely on the autonomy of EU law, on the monopoly of dispute settlement under Article 344 TFEU, on the co-respondent mechanism, on the procedure for the prior involvement of the Court and on the Common Foreign and Security Policy.

\footnotetext{
19 We borrow for this purpose from Eeckhout's paradigm of integration of the laws, eg see on the principle of limited and shared jurisdiction of courts: P Eeckhout, 'Human Rights and the Autonomy of EU Law: Pluralism or Integration?’ (2013) 66 (1) Current Legal Problems 169, pp 184-185.

20 See also A O'Neill, see note 3 above, who interpreted the Court's decision as a claim to be 'Master of the Treaties'.

21 See Opinion 2/13 (ECHR Accession II), EU:C:2014:2454, para 73.

22 For both the European Parliament and the Council see note 21 above, para 108 et seq.

23 See note 11 above, para 280.

24 See note 21 above, para 108 et seq.

25 Leaving out the four Member States that did not intervene in the procedure.

26 'And any man who must say 'I am the king' is no true king at all.' GRR Martin, A Storm of Swords (Harper Voyager, 2000), Chapter 53.

27 It is doubtful that the USA would agree to restrictions on a joint judicial body within the TTIP that would protect the autonomy of the EU and leave the CJEU on top.
} 


\section{THE AUTONOMY OF EU LAW}

The autonomy of EU law has been of constant high importance for the Court ever since its seminal decision in Van Gend en Loos. ${ }^{28}$ Following up on this case law, the Court also emphasises the notion of autonomy with particular vigour in a specific section of its Opinion. Put briefly, the Court understands autonomy to signify that the EU may be a construction of international law, but that in its internal order its own rules displace the principles and mechanisms of international law. ${ }^{29}$

In the Opinion, the Court recalls, however, its earlier case law based on which it is, as a matter of principle possible for the EU and its organs to submit themselves via an international agreement to a binding interpretation of the latter by an external judicial organ. ${ }^{30}$ This principle is nonetheless limited in that the competences of the EU must not be affected in their essential character by such interpretations. In particular, ECHR organs must not be able to bind the EU to a particular interpretation of rules of EU law. ${ }^{31}$ Arguably because it is reading these principled statements through its lens of exclusive autonomy, the CJEU then finds three issues because of which an accession of the EU to the ECHR based on the draft agreement could endanger the autonomy of EU law.

\section{A. The conflict between Article 53 ECHR and Article 53 Charter of Fundamental Rights}

First, the Court holds that the draft agreement does not make Article 53 ECHR compatible with Article 53 Charter of Fundamental Rights. Both provisions foresee that the relevant instrument is not to be interpreted as to adversely affect fundamental rights standards already granted in other ways by the respective Member States. The Court sees therein the problem that EU Member States could be permitted by means of Article 53 ECHR and in absence of a reconciling provision in the draft agreement to raise the level of protection of a fundamental right to the extent that the primacy, unity and effectiveness of EU law would be compromised (as already established in Melloni). ${ }^{32}$ The Court thus leaves room for renegotiation of the draft agreement in this respect so that its concerns can be met. It would thus have to be regulated that raising the level of protection of fundamental rights under the ECHR must neither affect the primacy of EU law for the EU Member States nor the unity and effectiveness of EU law. ${ }^{33}$

\footnotetext{
${ }^{28}$ See Van Gend en Loos v Administratie der Belastingen, EU:C:1963:1. Beiheft 2 Europarecht, p 25. doi:10.2139/ssrn.2605821.

31 See note 21 above, paras 183-184.

32 Stefano Melloni v Ministerio Fiscal, C-399/11, EU:C:2013:107.

33 See note 21 above, para 190.
}

${ }^{29}$ See also A Epiney 'Die Bindung der Europäischen Union an das allgemeine Völkerrecht' (2012)

${ }^{30}$ See note 21 above, para 182. Thereby following Opinion 1/76 (Inland Waterways) EU:C:1976:63; Opinion 1/91 (EEA Agreement) EU:C:1991:490; Opinion 1/00 (European Common Aviation Area) EU:C:2002:231; Commission v Ireland, C-459/03, EU:C:2006:345; Opinion 1/09 (Unified Patent Litigation System) EU:C:2011:123. See also P Eeckhout, 'Opinion 2/13 on EU Accession to the ECHR and Judicial Dialogue - Autonomy or Autarky?' (2015) 01/15 Jean Monnet Working Paper, p 4, 
However, a closer look reveals not only that this request will be hard to implement, but also that it appears to go beyond what is justified for two reasons; this even apart from the fact that the Court does not address to what extent the mentioned problems already exist in the current state of the law before an accession.

First, Article 53 ECHR, from a constitutional point of view, is not a provision on competence but a rule of construction that cannot limit or derogate from rights which are ensured under the laws of a member to the ECHR or other agreements made by these members. ${ }^{34}$ Therefore, it cannot grant rights that did not already exist and cannot resurrect Member State powers already denied by EU law. ${ }^{35}$ Despite the Court's exclusive view on the matter, accession in this regard would not compromise the primacy, unity and effectiveness of EU law and therefore would not undermine the Melloni findings. A discursive understanding would have accepted that also in future, Member States won't necessarily overstep the limits of their powers and that all the courts involved are able and willing to respect the limits of jurisdiction given by the law.

Second, the Court implies and requires that for the EU to accede to the ECHR only the Charter of Fundamental Rights is relevant for EU Member States within the scope of application of EU law, while the ECHR takes the backseat in terms of its substantive content. ${ }^{36}$ Thus, the CJEU requires that the European Court of Human Rights (ECtHR) effectively respects the CJEU's Melloni jurisprudence and thereby gives supremacy to the EU internal legal order over fundamental rights protection under the ECHR. This highly exclusive demand would be comparable in effect to a reservation by a party state to the ECHR which requires that the interpretation of ECHR rights by the ECtHR must not go further than the national interpretation of fundamental rights. This appears to be extremely difficult to reconcile with the very object and purpose of the ECHR.

In this regard, the CJEU also missed an opportunity to opt for a discursive stance and state its views on the effects of an accession on Article 52 (3) of the Charter, according to which the rights granted in the Charter of Fundamental Rights which correspond to rights granted under the ECHR have the same content and scope as the latter.

From a human rights point of view, therefore, Article 52 (3) of the Charter already contains a mechanism in EU law which reconciles the scope and content of fundamental rights in the Charter and the ECHR to a considerable extent. For most EU fundamental rights, the jurisprudence of the ECtHR is thus already relevant and binding. ${ }^{37}$ Within the scope of application of EU law, national courts can already apply higher standards of fundamental rights protection based on the ECHR and are, in cases of doubt, obliged to submit a question to the CJEU in the context of a preliminary reference procedure. Although this approach would follow a more discursive rationale and puts more trust in the Member States' courts, it simultaneously

\footnotetext{
34 Article 53 ECHR.

35 D Halberstam, see note 5 above, p 125.

36 T Lock, see note 3 above.

37 See also S Peers and S Prechal 'Art. 52 - Scope of Guaranteed Rights' in S Peers et al, The EU Charta of Fundamental Rights (Hart Publishing, 2014) para 52.123.
} 
adequately ensures that the Court has the last word on the standard of protection applicable in EU law. ${ }^{38}$

From a constitutional point of view, however, an accession would undoubtedly also have an effect on the autonomy of the EU with regard to Article 52 (3) of the Charter. Whereas the CJEU is now relatively free in its interpretation of ECtHR's jurisprudence and remains thereby to some extent in control of the interpretation of EU human rights law as supreme court of the EU, after accession, Article 52 (3) of the Charter would to some degree lose its function as the EU as well as the CJEU would be directly bound by ECtHR case law with the ECHR as an integral part of EU law after accession. ${ }^{39}$ A non-EU court would thus become the supreme interpretive authority of EU human rights law. ${ }^{40}$

The Court thus perceives its change of function as the ultimate interpretive authority of EU fundamental rights in case of an accession as a threat to the (exclusive) autonomy of EU law. However, it fails to consider thereby whether this to some extent inevitable - development can be accommodated under a more discursive conception of autonomy, casting doubt on its earlier jurisprudence that as a matter of principle, the EU and its institutions can sign up to international agreements containing binding judicial dispute settlement mechanisms. ${ }^{41}$

\section{B. The requirement to check whether another Member State has observed fundamental rights under the ECHR}

As a second problem, the Court perceives a danger for the autonomy of EU law in the draft agreement because it may adversely affect the principle of mutual trust between the Member States concerning the respect of fundamental rights, which is particularly relevant in the Area of Freedom, Security and Justice. ${ }^{42}$ According to the Court the draft agreement provides for an obligation of Member States to check the observance of all other party states even if they are EU Member States. ${ }^{43}$ Again, although there would have been other legal avenues open to the Court, it decided to stick to an exclusive paradigm of autonomy and refused to consider such alternatives.

Indeed it can be taken as a fact that the mutual checking of observance of fundamental rights under the ECHR impairs the principle of mutual trust. The Court's dicta, however, do not address that the relevant obligation already binds the EU Member States today. Furthermore, a more conciliatory argument more in line with a discursive conception of autonomy could have been made at this point. In the case law of the ECtHR mutual checking of the observance of fundamental rights is typically required where substantial violations of ECHR rights would be caused by

\footnotetext{
38 W Michl, 'Thou shalt have no other courts before me' (23 December 2015) Verfassungsblog http:// www.verfassungsblog.de [last accessed 8 July 2015].

39 Haegmann v Belgium, C-181/73, EU:C:1974:41, paras 2-6.

40 For a similar argument in CFSP matters, see D Halberstam, note 5 above, p 141.

41 Opinion 1/92 (European Economic Area), EU:C:1992:189, paras 31 and 42.

42 See note 21 above, para 191 et seq.

43 Ibid, para 194.
} 
the surrender of persons to another state - eg in the framework of the Dublin system. ${ }^{44}$ A deviation from the principle of mutual trust in EU law is, however, typically only permitted in cases of extraordinary circumstances, which arguably requires a graver and more systematic violation of Convention rights. ${ }^{45}$ It is deplorable that the Court only recognises the divergence of standards in this matter as a problem without trying in any way to align EU law with the higher standard of protection given under the ECHR. In its exclusive focus on maintaining the full autonomy of EU law, the Court thereby sustains the principle of mutual trust practically at all costs.

In addition, one might say that the danger for mutual trust may be even higher without an accession to the ECHR. To put it differently, mutual trust in human rights law may already be overstretched. ${ }^{46}$ Having opted for exclusivity may prove detrimental for the Court in this regard. The Member States and their courts are stuck in between the CJEU's approach to generally trust the Member States' human rights protection and individual scrutiny imposed by the ECtHR. As a consequence, Member States courts following the Solange-approach may find themselves, eg in Dublin cases, in accordance with the CJEU when they trust the procedures for the protection of human rights in other Member States, ${ }^{47}$ while at the same time violating human rights in the eyes of the ECtHR by not reviewing the individual situation. The CJEU may therefore already now face the risk that, in order to resolve this tension, the Member States' highest courts start to reconsider their Solange-approach and give up mutual trust in favour of individual scrutiny to comply with the ECHR's standards. To solve this problem, one could suggest that with accession and the co-respondent mechanism combined, the EU provides for a possibility to preserve mutual trust by intervening in ECtHR procedures as a co-respondent. In that way, the EU could take the responsibility at the ECtHR for implementing a system of general trust among Member States in each other's system of human rights protection while at the same time the Member States (or their courts respectively) can comply with the principle of mutual trust and individuals are provided with individual scrutiny by the ECtHR. ${ }^{48}$ This would of course require the Court to abandon its exclusive stance and allow the accession as a tool to establish a clearer, more discursive system where trust is put in the ECtHR to exercise its own jurisdiction appropriately.

\section{Requests for advisory opinions by national highest courts to the ECtHR on questions of principle}

For the CJEU the third danger for the autonomy of EU law consists of the possibility granted by Protocol 16 to the ECHR for the highest courts of Member States to ask

\footnotetext{
44 See Tarakhel $v$ Switzerland (Application no. 29217/12) (2014).

45 NS v Secretary of State for the Home Department, C-411/10, EU:C:2011:865.

46 D Halberstam, see note 5 above, p 126.

47 See N.S., C-411/10, EU:C:2011:865, para 94; Abdullahi, C-394/12, EU:C:2013:813.

48 D Halberstam, see note 5 above, p 134; S Douglas-Scott, 'Opinion 2/13 and the 'Elephant in the Room': A Response to Daniel Halberstam' (13 March 2015) Verfassungsblog http://www. verfassungsblog.de.
} 
the ECtHR questions on the interpretation or application of fundamental rights. ${ }^{49}$ The Court holds that although an accession of the EU to Protocol 16 was not foreseen in the draft agreement, the ECHR would nonetheless become part of EU law, with the effect of the preliminary ruling procedure of Article 267 TFEU potentially losing effectiveness. The highest courts of those Member States which ratified Protocol 16 could also ask the ECtHR for advisory opinions falling within the scope of EU fundamental rights. Therefore, a mechanism is needed in the eyes of the Court to regulate the relationship between these two mechanisms and to ensure the autonomy and effectiveness of the preliminary ruling procedure. ${ }^{50}$

The exclusive conception of autonomy of the Court becomes visible in the distrust put in Member States' highest courts and their use of the procedure under Protocol 16. Indeed it cannot be excluded that the entry into force of Protocol 16 may effectively have some negative effects on the role of the CJEU. From a constitutional point of view, the ECHR would after accession become an integral part of EU law. ${ }^{51}$ The CJEU would therefore become the authorised interpreter of the ECHR-as-EU-law for all matters. ${ }^{52}$ The ratification of Protocol 16 by EU Member States would impose difficult questions on Member States' courts. They would have to decide whether the CJEU or the ECtHR would be the right instance for asking preliminary questions in human rights matters. Asking the wrong court could not only result in infringement proceedings for the Member States, but also in an undue delay for the legal protection of individuals against possible violations of human rights. Nonetheless, for a number of reasons the Court's reasoning is overtly exclusive. As a starting point, it must be taken into account that the opinions handed down by the ECtHR are non-binding. ${ }^{53}$ Furthermore, as the Advocate General found, such negative effects would not be an effect of the accession of the EU to the ECHR. ${ }^{54}$ Even without such an accession the courts of EU Member States who ratified Protocol 16 can ask for advisory opinions from the ECtHR.

In any event, contrary to the Court's view, this problem already finds its solution in the Treaties. Based on Article 267 (3) TFEU, the courts of last instance of the Member States are obliged to submit EU law questions in the framework of a preliminary ruling procedure to the CJEU. This obligation undeniably enjoys primacy over the obligations of Member States as parties to the ECHR as they would result from Protocol 16. ${ }^{55}$ To address the concerns of the CJEU it has additionally been suggested that the Member States could add binding unilateral declarations to Protocol 16 to provide a solid legal basis for the ECtHR to refuse jurisdiction when a Member State's court wrongly requests an advisory opinion despite the fact that the

49 Currently not yet in force.

50 See note 21 above, para 196 et seq.

51 See note 39 above, para 2-6.

52 D Halberstam, see note 5 above, p 121.

53 Article 5 of Protocol 16 to the ECHR.

54 See note 11 above, para 140.

55 Ibid, para 141. 
question falls within the competence of the CJEU. ${ }^{56}$ Should a Member State's court of last instance nonetheless submit a question within the scope of EU law to the ECtHR without being entitled to do so under the acte-clair-doctrine, ${ }^{57}$ infringement proceedings could be engaged against that Member State based on Article $258 \mathrm{f}$ TFEU. The Court's request for an explicit mechanism is thus ultimately unjustified and is hard to explain by other reasons than the Court's exclusive vision of autonomy.

\section{THE MONOPOLY OF DISPUTE SETTLEMENT UNDER ARTICLE 344 TFEU}

The monopoly of dispute settlement maintained by the EU courts under Article 344 TFEU obliges the Member States to settle disputes concerning the interpretation or application of the Treaties by no other means than the ones provided for in the latter and thereby strengthens the jurisdictional order of competences within the EU. Here, the Court sees a danger for this order. Based on an exclusive perspective on the autonomy of the EU legal order, it requires far-reaching safeguards which, however, prove excessive on closer inspection. Article 5 of the draft agreement provides that proceedings of the Member States before the CJEU ought not to be considered as proceedings in the sense of Article 55 ECHR. ${ }^{58}$ Nonetheless, based on Article 33 ECHR, EU Member States could still have the possibility to start proceedings against other Member States or the EU itself. Even the mere existence of this possibility does not comply with Article 344 TFEU in the eyes of the Court and would be incompatible with the latter provision's exclusive character. ${ }^{59}$ This tension can only be resolved by means of an express exclusion of the competence of the ECtHR under Article 33 ECHR for disputes between EU Member States, or between them and the EU, which concern the application of the ECHR within the scope ratione materiae of EU law. ${ }^{60}$

The CJEU thereby demands the inadmissibility of all state complaints in front of the ECtHR as far as the relevant provisions of the ECHR also fall within the scope of EU law and Member States or the EU itself are on the applicant and the respondent side. Based on the Court's request, Article 344 TFEU would thus be exported to the level of international law, with the consequence of the EU becoming part of an international legal framework that provides for a dispute settlement system which at the same time the EU would partly deny to its Member States. ${ }^{61}$ Nonetheless, this demand appears excessive for four reasons which simultaneously show that an approach more open to discursive autonomy would have been possible, if sufficient

56 D Halberstam, see note 5 above, p 122.

57 CILFIT v Ministero della Sanità, C-283/81, EU:C:1982:335, para 13 et seq.

58 See note 21 above, para 201 et seq.

59 See note 21 above, paras 208 and 212.

${ }^{60}$ See note 21 above, para 213.

${ }^{61}$ D Halberstam, see note 5 above, p 119. 
trust would have been put in the other actors' preparedness to respect their own limits of competences.

First, a demand for disconnection clauses (eg Article 282 United Nations Convention on the Law of the Sea) contradicts the general praxis of international agreements by creating an exception for the major part of parties excluding them from the dispute settlement procedure without opening this possibility for the other parties to the agreement. ${ }^{62}$ It is highly likely that such an exception would meet little acceptance by the other Member States of the Council of Europe and might render accession as provided for in Article 6 (2) TEU difficult, if not impossible. The Court thus already excludes any discussion of EU law by international adjudicators' right from the start.

Second, this demand would simultaneously mean that numerous agreements already concluded by the EU are also in contradiction to Article 344 TFEU as they do not contain such exception provisions. ${ }^{63}$

Third, in this case EU Member States would also find themselves under an obligation under Article 351 (2) TFEU to amend a number of existing agreements. As soon as two or more EU Member States - as in MOX Plant - form parties to an agreement with a dispute settlement mechanism and provisions that overlap in substance with EU law, the monopoly of dispute settlement under Article 344 TFEU would thus be endangered and the relevant agreement as such incompatible with the autonomy of EU law. ${ }^{64}$

Fourth, it remains questionable whether the autonomy of EU law is really exclusive to such an extent that it must be secured by imposing on non-Member States that they have to expressly guarantee the respect of the monopoly of the CJEU on dispute settlement within the EU regarding the provisions of an international agreement. ${ }^{65}$ The suggestion made by the Advocate General is more convincing in this regard. It should thus be sufficient to start infringement proceedings based on Article $258 \mathrm{f}$ TFEU against EU Member States if they settle their disputes before other international instances. ${ }^{66}$ This is at the same time a much more open and discursive solution, as no major obstacle for the very negotiation of international agreements in the future is created. As an additional measure to ensure the practical effectiveness of Article 344 TFEU EU Member States could be obliged, before the accession of the EU to the ECHR, to declare with binding force under international law that they will not engage proceedings under Article 33 ECHR whose object of dispute falls within the material scope of EU law. ${ }^{67}$

\footnotetext{
62 See note 11 above, para 115 et seq; SO Johansen, 'The Reinterpretation of TFEU Article 344 in Opinion 2/13 and Its Potential Consequences', (2015) 16 (1) German Law Journal 169, p 176.

63 See note 11 above, para 117.

64 For similar arguments see T Lock, 'Autonomy now?! A brief response to Daniel Halberstam'

(12 March 2015) Verfassungsblog http://www.verfassungsblog.de.

65 See also M Wendel, note 3 above.

66 See note 11 above, para 118.

67 See also D Halberstam, note 5 above, p 120.
} 


\section{THE CO-RESPONDENT MECHANISM}

Article 3 of the draft agreement sets out the so-called co-respondent mechanism in which several member-states and/or the EU might have to respond jointly for a particular violation of the ECHR. Based on arguments of both respondent and co-respondent, this might allow the ECtHR to at least review some internal responsibilities in the EU. It should be noted from the outset that the concerns of autonomy raised by this mechanism are to some extent legitimate and their treatment by the Court acceptable also from a perspective of discursive autonomy. Discursive autonomy, as discussed above, does not mean that there are no longer any constraints anymore for a project like the accession of the EU to the ECHR. Nonetheless, a number of findings of the Court on this aspect of the draft agreement again demonstrate an exaggerated insistence on the exclusive nature of the EU legal order's autonomy.

The first part of Article 3 (7) provides that the respondent and the co-respondent are jointly responsible for a violation of the ECHR, which should prevent the ECtHR from having to decide, based on EU law, who is responsible for a particular violation. ${ }^{68}$ Based on the co-respondent mechanism the Union or an EU Member State can become full parties to proceedings with all corresponding rights and obligations whenever the examination of a violation of the ECHR implies also the scrutiny of a provision of EU law as to its compatibility with the ECHR. This is the case in particular where a violation would only have been avoided by means of a violation of EU law. ${ }^{69}$ The draft agreement provides for two possibilities. Based on Article 3 (5), the ECtHR can invite a party to the ECHR to become co-respondent or decide on a request to intervene as a co-respondent. In the latter case, the ECtHR has to verify whether the relevant requirements are plausibly fulfilled. The CJEU criticises this point holding that it must be left to the EU and its Member States to examine whether the requirements for the co-respondent mechanism are met. $^{70}$

The mere invitation procedure fulfils this condition according to the CJEU, as the invitation itself is not binding. Accordingly, a party cannot be obliged to participate in proceedings; also, the EU and its Member States thereby retain the power to examine whether the material requirements are fulfilled - which necessarily includes a decision based on EU law. For this purpose, it is indispensable to apply the rules of EU law on the distribution of competences between the EU and the Member States and the criteria for accountability to the EU or the Member States. ${ }^{71}$

In the case of a request to intervene as a co-respondent by either the EU or a Member State, however, the requesting party must provide arguments showing that the requirements are met. As a consequence, the Court would be called to examine not the arguments themselves in-depth, but nonetheless their plausibility.

${ }^{68}$ See note 11 above, para 176 .

69 See note 21 above, para 55 et seq.

70 Ibid, para 220.

71 Ibid, para 220 et seq. 
According to the CJEU, this is 'liable' to interfere with the division of powers between the EU and the Member States and is thus inadmissible. ${ }^{72}$

The Court's approach appears highly exclusive in this context and puts no trust at all in an external judiciary having some sort of say on rules of EU law. Arguably, the intensity of review used by the ECtHR in all likelihood will be rather low; moreover, no effectively binding interpretation of the distribution of powers takes place. ${ }^{73}$ Also from the perspective of the ECtHR, there should not even be much of an interest in determining such internal matters of the relationship between the EU and the Member States. With accession, one could think of three possibilities in how to address the situation of potentially joint responsibility in proceedings before the ECtHR: first, complaints against the EU or a Member State always lead a co-response by the EU or the Member States; second, complaints would never lead to a co-response; or third, complaints would lead to a co-response if plausible. The first two options would certainly impose a threat on the autonomy even under a discursive understanding, because they would completely disregard the distribution of competences in the EU. A plausibility check if exercised correctly, ${ }^{74}$ however, is already the most respectful solution for the autonomy of the EU, because it can thereby be left to the EU and the Member States to internally address the institution in charge and help to effectively address violations of the ECHR. Usually, the plaintiff's first priority in a justified claim in ECtHR proceedings would be to end the violation of her fundamental rights by the respondent(s), followed by the second priority to receive just satisfaction. ${ }^{75}$ Therefore, the internal distribution of competences on the respondent's side would be of lesser if not of no importance for both the plaintiff and the ECtHR. The internal distribution of competences and consequently of liability would remain a question to be solved within the EU, creating thus a satisfactory solution under a discursive understanding of autonomy which allows such a discussion of EU law by the ECtHR as a matter of principle.

As a further point of criticism, the Court finds fault in the joint responsibility provided for in Article 3 (7) of the draft agreement for the respondent and the co-respondent. This could lead to a Member State being held to be responsible together with the EU of a violation of a provision of the ECHR in respect of which said Member State has made a reservation. ${ }^{76}$ This would contradict Protocol 8 to the Treaties which prescribes that the agreement on the accession of the EU to the ECHR has to ensure that nothing therein affects the particular situation of the Member States in relation to the ECHR, in particular in relation to reservations.

Again, the approach pursued by the Court is clearly excessively exclusive. First, the EU can only become co-respondent in proceedings relevant to EU law when a Member State is respondent in front of the ECtHR. This is already excluded if there

72 Ibid, para 223 et seq.

73 T Lock, see note 3 above.

74 Coram iudice et in alto mari sumus in manu Dei.

75 A Peters and T Altwickler, Europäische Menschenrechtskonvention, $2^{\text {nd }}$ ed $(\mathrm{CH}$ Beck, 2012), p 286.

76 See note 21 above, para 227. 
is a reservation by that Member State. ${ }^{77}$ Second, neither will the ECtHR invite a Member State to intervene as co-respondent if there exists a relevant reservation by that Member State, nor will a Member State request to intervene in such a case. It therefore remains unclear how the joint responsibility mechanism is supposed to overrule an existing valid reservation in practice. Exclusive autonomy thus seems to lead the Court to even find a problem in the law where at a closer look there is none.

Finally, the CJEU criticises - arguably correctly under any perspective on autonomy - that according to Article 3 (7) of the draft agreement the ECtHR could decide based on the arguments of the respondent and the co-respondent, having sought the views of the applicant, that only one of the two is responsible for a violation. This would constitute necessarily a decision based on EU law concerning the distribution of powers. As that decision is taken by the ECtHR, it could adversely affect this distribution. ${ }^{78}$ This assessment would also remain the same if the ECtHR were to decide exclusively based on the arguments of the respondent and the co-respondent without hearing the applicant; even if by these means the ECtHR would merely 'confirm' an agreement reached by the respondent and the co-respondent on the distribution of responsibility, this would concern a question falling within the exclusive competence of the CJEU. ${ }^{79}$ Contrary to the cases of the plausibility check and of Member States' reservations to the ECHR, even a discursive understanding of autonomy cannot be reconciled with this particular situation where an external court determines with binding force an element intrinsic to the distribution of competences.

\section{THE PROCEDURE FOR THE PRIOR INVOLVEMENT OF THE CJEU}

The procedure for the prior involvement of the CJEU provided for in Article 3 (6) of the draft agreement intends to ensure that the Court obtains the opportunity and necessary time to examine the compatibility of provisions of EU law with the ECHR if it did not have a prior opportunity to do so. In a similar vein as in the previous section, the Court's reasoning can be criticised to some extent, but remains convincing in other respects where even a discursive understanding of autonomy must necessarily find its limits.

For the Court, the prior involvement procedure is indispensable not only for reasons of subsidiarity as they result from the mechanism of supervision established by the ECHR, but also to ensure the proper functioning of the EU judicial system. For this purpose the CJEU holds that the question of whether the Court has already ruled on a particular legal question necessarily has to be decided by an EU organ and in a manner binding for the ECtHR. Otherwise, the competence to interpret the jurisprudence of the CJEU would be transferred to the ECtHR. As a consequence, the Court finds that Article 3 (6) of the draft agreement in its current form is

77 T Lock, see note 3 above.

78 See note 21 above, para 230 et seq.

79 Ibid, para 234. 
incompatible with those principles, as it does not ensure that the EU is 'fully and systematically' informed in any case pending before the ECtHR, which would be necessary to allow the competent institution to assess whether the prior involvement procedure has to be triggered. ${ }^{80}$ In particular, the ECtHR has no systematic collection of all pending and received complaints as the CJEU does in form of the Official Journal of the EU. ${ }^{81}$

While this in principle appears convincing, the question arises whether the duty of full and systematic information must necessarily be regulated in the accession agreement. Again, the exclusive autonomy perspective leads the Court to request extensive safeguards in the agreement before accession can take place, rather than to resolve the problem by integrating the problem into the EU legal order. Based on the duty of loyal cooperation of the Member States this problem could also be resolved within the EU in the form of a more concrete EU legal act. ${ }^{82}$

At the same time, the CJEU finds fault in the interpretation given to Article 3 (6) by the draft explanatory report; the report stated that the provision ought to mean that the CJEU would only examine the compatibility with ECHR with respect to the interpretation of primary law and the validity of secondary law, but not with respect to the interpretation of secondary law. Apparently matters of interpretation of secondary law could thus not be brought before the Court. ${ }^{83}$ It would violate the exclusive competence of the CJEU to interpret EU secondary law in a binding manner if as a consequence the ECtHR had to decide for itself on a plausible interpretation of secondary law in this context. ${ }^{84}$

The Court's analysis is certainly convincing in this respect. Even if discursive autonomy would not prohibit an interpretation of EU secondary law by the ECtHR, this cannot go as far as to let the ECtHR decide on its own in a binding manner without the CJEU having its say in this constellation. However, from the perspective of discursive autonomy it can be criticised in that again a problem should be resolved at the international legal level of the accession agreement that is - at the end of the day - essentially an internal one of the EU legal order, namely the potential disrespect by national courts of the duty to refer EU law questions to the Court. ${ }^{85}$ In purely substantive terms the arguments of the Court are, however, correct. In theory, one could of course try to interpret the notion of '[a]ssessing the compatibility' broadly so that cases of interpreting EU secondary law would be included. However, the draft explanatory report that according to the express will of its drafters enjoys the same authority as the draft agreement itself expressly casts doubt on such a reading. Even a discursive conception of autonomy does not help at this point, as it

\footnotetext{
80 Ibid, para 236 et seq.

81 The argument about an indirect duty to inform imposed on the Member States based on the duty of loyal cooperation was not taken up by the Court, see note 11 above, para 224 et seq.

82 M Wendel, see note 3 above.

83 See note 21 above, para 242 et seq.

84 Ibid, para 246.

85 M Wendel, see note 3 above.
} 
must be based on the law as it stands. An amendment and clarification in a future draft agreement is thus indispensable. ${ }^{86}$

\section{THE COMMON FOREIGN AND SECURITY POLICY}

For the purposes of the Common Foreign and Security Policy (CFSP), the jurisdiction of the Court is limited in the Treaties to whether Article 40 TEU has been respected and to the review of legality of certain decisions taken based on Article 275 (2) TFEU, the latter concerning essentially legal actions brought against the legality of decisions on restrictive measures against natural and legal persons, taken by the Council. The problem therefore lies in the question as to what extent the ECtHR can have jurisdiction to examine the compatibility of EU legal acts with the ECHR without the CJEU being able to express its views on such acts. The Court again chose to follow an exclusive path, finding that in case of doubt it would be better for no one to have jurisdiction rather than to accept that the Treaties may in this case point towards discursive autonomy that grants interpretative power to other actors.

The Commission had argued that a systematic interpretation would be possible according to which the Court would have a sufficiently large jurisdiction. As a consequence of such an interpretation, all cases would be encompassed which could potentially form the basis of a complaint under the ECHR, which are annulment actions, but also actions in damages and preliminary ruling procedures engaged by national courts in the area of the CFSP. ${ }^{87}$ However, the Court had severe doubts in this regard, as it did not yet have the opportunity to address the extent of the limitations of its jurisdiction in the area of the CFSP. Because of the limitation of the CJEU's jurisdiction in the Treaties, according to the Court, an accession based on the draft agreement would currently lead to a situation where the judicial control of the relevant acts or omissions of the EU with regard to their compatibility with the ECHR would be exclusively attributed to an organ external to the EU. As held in earlier jurisprudence, this would be inadmissible. ${ }^{88,89}$

In merely dogmatic terms, the Court is certainly correct in its interpretation of Article 275 (2) TFEU. The interpretation suggested by the Commission is hardly convincing: the provision already systemically forms an exception from the rule that the CJEU has no jurisdiction. Furthermore, its wording only refers to annulment actions brought by individuals based on the conditions of Article 263 (4) TFEU and

\footnotetext{
86 See note 11 above, para 132 et seq.

87 It should be noted in this regard that the General Court has recently decided cases on actions in damages without addressing expressly the problem of a potential lack of jurisdiction, see General Court, Case T-384/11, Safa Nicu Sepahan v. Council, EU:T:2014:986; Case T-293/12, Syria International Islamic Bank PJSC v. Council, EU:T:2014:439. However, at the time of writing the CJEU has not yet pronounced itself on this question.

88 Opinion 1/09 (Unified Patent Litigation System), EU:C:2011:123.

89

See note 21 above, para 251 et seq.
} 
not, as suggested by the Commission, to other kinds of proceedings. ${ }^{90}$ By contrast, the fundamental rejection of giving jurisdiction to the ECtHR is understandable as part of the exclusive paradigm followed by the Court, but at the same time less convincing as the rather short-hand answer given by the Court makes it appear. One can already note with curiosity that the Court here makes exclusive statements on jurisdiction, thereby extending its own exclusive jurisdiction to an area where - based on the Treaty - this jurisdiction is expressly excluded. ${ }^{91}$

A closer look at the area of the CFSP shows that, from an integrationist perspective, one may regret the decision taken by the drafters of the Lisbon Treaty; ${ }^{92}$ however, it must be accepted that they intentionally created a situation where the national courts take the place of the CJEU, which therefore also prevents the emergence of any problem of violation of the latter's exclusive jurisdiction. A discursive understanding of autonomy would be able to accommodate this. In the case of the CFSP, the national courts replace the CJEU and have to ensure effective judicial protection of individuals also in the absence of the Court's competence to make preliminary rulings and its monopoly to annul EU law. ${ }^{93}$ The Court's reasoning is, by contrast, hardly convincing and excessively exclusive in this regard, as problems of conflicting jurisprudence and dangers for the EU's supranational structure cannot emerge when an international court is granted more far-reaching jurisdiction than the EU courts. ${ }^{94}$

This was explicitly taken into account by the drafters of the Lisbon Treaty when they regulated both the accession of the EU to the ECHR and the limited jurisdiction of the CJEU in CFSP matters in the Treaties. ${ }^{95}$ With regard to this point the Court's reasoning appears thus to exceed what is dogmatically convincing, with the result that in an area where much could be gained by accession to the ECHR from the perspective of individuals in terms of judicial control, the Court finds it preferable that no one has jurisdiction rather than the ECHR being granted this privilege. ${ }^{96}$ What is more, the Court's highly exclusive dicta seem to point in a direction where even an interpretation of the provisions of the CFSP acts by the International Court of Justice in The Hague would appear problematic, and Member States could accordingly see themselves threatened by infringement proceedings if they participate in such proceedings. ${ }^{97}$

Even more nuanced proposals of exclusive autonomy find their limits in the text of the Treaties in this regard. Some argue that the drafters of the Lisbon Treaty had the intention to not only keep the CJEU out of CFSP matters, but also any other

\footnotetext{
90 See note 11 above, para 89.

91 T Lock, see note 3 above.

92 See note 11 above, para 101 et seq.

93 Ibid, para 102.

94 Ibid, para 193.

95 Ibid, para 194.

96 M Wendel, see note 3 above.

97 S Peers, 'The CJEU and the EU's Accession to the ECHR: A Clear and Present Danger to Human Rights Protection', see note 3 above.
} 
international court. An accession in terms of the draft agreement would have turned the ECtHR into the supreme court of the EU in matters of the CFSP by supervising the Member States' courts in terms of compliance with the Convention. Combined with Protocol 16, the accession would have also created a system for CFSP advisory opinions leaving out the CJEU, ${ }^{98}$ although it is still part of the EU legal order. ${ }^{99}$ It is seen as problematic that whereas the Treaties waive the consolidating function of the CJEU in CFSP matters, the draft agreement would have outsourced it. ${ }^{100}$ Regrettable as this might seem to some, the overall conclusion remains nonetheless that this result following a more discursive paradigm is the consequence of the choices of the Treaty drafters.

However, at this point it becomes clear that discursive autonomy also entails a cost. Without an internal consolidation mechanism in CFSP matters and the co-respondent mechanism enshrined in the draft agreement, the EU might have been held responsible for the decisions of Member States' courts on which the CJEU would have had no influence. It is not difficult to imagine a Member State's court's decision, which the CJEU if asked would have decided differently. Member States' high court decisions would have entailed direct international responsibility for the EU as a whole without the possibility to let the CJEU review the matter. ${ }^{101}$ The Court seems to have found the costs of discursive autonomy too great to bear and decided therefore in favour of exclusive autonomy in the sense of excluding the ECtHR from having jurisdiction in CSFP matters.

\section{OUTLOOK}

\section{A. General evaluation}

The general reaction of scholars to Opinion 2/13 has been overwhelmingly negative. As a representative remark, it has been stated that in light of the overall objective of submitting the EU to an external system of judicial fundamental rights review, the Court's findings seem to overemphasise the autonomy of the EU legal system and do not ask sufficiently what could be acceptable losses of autonomy indispensable to the achievement of the stated objective. ${ }^{102}$ This corresponds with our assessment under the notions of discursive and exclusive autonomy: the Court has favoured the latter unduly for a number of aspects, the conflict between Articles 53 ECHR and 53 of the Charter, the principle of mutual trust in the Area of Freedom, Security and Justice, the requests for advisory opinions under the ECHR Protocol 16 and the monopoly of dispute settlement under Article 344 TFEU. For the sake of fairness, it should be underlined that a solution justified even under the perspective of discursive autonomy has been found by the Court for some aspects of the co-respondent mechanism and the procedure for the prior involvement of the CJEU. In the area of

\footnotetext{
98 D Halberstam, see note 5 above, p 141.

99 D Halberstam, see note 5 above, p 137 et seq.

100 D Halberstam, see note 5 above, p 142 et seq.

101 D Halberstam, see note 5 above, p 143.

102 S Douglas-Scott, see note 3 above.
} 
CSFP, the cost of a discursive solution would have been admissibly high, which may to some extent explain, though not perfectly justify the Court's decision.

Nonetheless, even taking into account these nuances in the exclusive autonomybased reasoning of the Court, the view of Advocate General Kokott demonstrates that a different, more discursive solution would have been possible. Despite her criticism of a number of points in the draft agreement, the Advocate General suggested that the Court ought to avoid pronouncing the draft agreement incompatible with the Treaties, but instead hold that it was compatible if certain amendments were undertaken following the Court's opinion. ${ }^{103}$ Before this background, one can legitimately ask whether the Court's exclusive approach is justifiable in the light of Article 6 (2) TEU which can certainly be read as encompassing a duty of best efforts towards accession of the EU to the ECHR. Instead of at least opting for a somewhat encouraging wording that could serve as a road map for the Commission, the Court, however, decided to hand down a no, spread over nine pages. If we compare at this point the external to the internal perspective, it also appears hard to digest that in its relationship with external judicial bodies the Court follows an approach of exclusive autonomy, when at the same time the cornerstones of the EU judicial system consist of elements like the preliminary ruling procedure and of the acceptance of discursive autonomy by the Member States and their courts.

\section{B. How to move on?}

The Opinion will generally render future accession highly difficult and also delay it, since the negotiations of the draft agreement have already proved protracted and complex, and since the draft agreement already took into account suggestions by the CJEU, which was represented in the relevant Council committee. ${ }^{104}$

A number of concrete proposals have been brought forward as a reaction to Opinion $2 / 13$. Some argue that accession would no longer make sense under the conditions given by the CJEU, as this would not allow the creation of an effective external surveillance mechanism of EU action with regard to fundamental rights protection. ${ }^{105}$ Others propose an amendment of EU primary law - presenting an open snub towards the Court. ${ }^{106}$ Politically, however, this appears to be highly difficult, as such an amendment would need to be comprehensive and tackle a number of points. ${ }^{107} \mathrm{~A}$ rather extreme suggestion openly calls for political disobedience against the CJEU: a protocol should be drafted that allows accession of the EU to the ECHR notwithstanding Opinion 2/13. ${ }^{108}$ A renegotiation of the draft agreement would be hardly realistic given the notable unwillingness of negotiating partners such as Russia or Switzerland. Again others see the opinion as a welcome

\footnotetext{
103 See note 11 above, para 279.

104 S Douglas-Scott, see note 3 above.

105 Ibid.

106 M Wendel, see note 3 above.

107 T Brings, 'Änderungen der EU-Verträge zugunsten des europäischen Grundrechtsschutzes?' (5 February 2015) Junge Wissenschaft http://www.juwiss.de/5-2015/ [last accessed 8 July 2015].

108 LFM Besselink, see note 3 above.
} 
step that gives the EU more time to develop its internal mechanisms for fundamental rights protection, in particular those based on the Charter of Fundamental Rights, before an external surveillance mechanism is installed. Another alternative proposal foresees an amendment of the Treaties which clarifies the status of the ECHR within EU law and upgrades it to ensure, instead of an accession to the ECHR, a more coherent observance of the ECHR acquis. ${ }^{109}$ Other commentators suggest an amendment of Article 6 (2) TEU by removing Sentence 2 and Protocol 8 to clarify the importance of accession. ${ }^{110}$

At the end of the day, in our view, hard work will be required by those still in favour of accession to bring the concept of a more discursive autonomy of EU law closer to the hearts and minds of the EU judiciary and many EU lawyers. In light of the Court's highly restrictive reasoning in Opinion $2 / 13$, a veritable change of paradigm seems to be inevitable before any further successful steps on the still long and rocky road to accession can be undertaken.

\section{The perspective of the ECtHR}

Some speculation has also arisen with regard to what changes for the ECtHR as a result of Opinion 2/13 and the openly exclusive attitude exhibited by the CJEU. In particular, one may wonder whether the Bosphorus presumption developed in the ECtHR's jurisprudence could now be questioned. ${ }^{111}$ Under this presumption, the ECtHR did not fully release EU Member States of their responsibility for having transferred their activities to the level of an international organisation like the EU, but established after a thorough investigation that the EU's system of fundamental rights protection according to the state of the law at the time was appropriate in the sense of the ECHR. Early reactions from the ECtHR have already been interpreted as possible signs for less close cooperation between the two courts in the future. ${ }^{112}$

\footnotetext{
109 For both proposals see: J Morijn, 'After Opinion 2/13: how to move on in Strasbourg and Brussels?' (5 January 2015) EUtopia Law http://eutopialaw.com [last accessed 8 July 2015].

110 SO Johansen, see note 62 above.

111 Bosphorus v Ireland (Application no. 45036/98) (2009).

112 See T Lock, 'Will the Empire Strike Back? Strasbourg's Reaction to the CJEU's Accession Opinion' (30 January 2015) Verfassungsblog http://www.verfassungsblog.de; D Hart 'Dogfight Continues: Strasbourg Not Happy with EU Court on Accession to ECHR' (30 January 2015) UK Human Rights Blog http://ukhumanrightsblog.com [last accessed 8 July 2015].
} 